\title{
METODE PENCUPLIKAN NILAI ECHO CITRA RADAR *.PNG DENGAN REFERENSI SPASIAL DAN KOMBINASI WARNA RGB
}

\author{
Sampling Method of Echo Value from *.PNG Radar Image with Spatial \\ Reference and RGB Colour Combination
}

\author{
Purwadi $^{1)^{\star}}$, Lutfi Fitriano ${ }^{2}$ \\ 1) Balai Besar Teknologi Modifikasi Cuaca - Badan Pengkajian dan Penerapan Teknologi, Gedung Ir. \\ Mohammad Soebagio, GEOSTECH (820), Kawasan PUSPIPTEK, Serpong, Tangerang Selatan \\ ${ }^{2)}$ Badan Meteorologi, Klimatologi dan Geofisika (BMKG), Jl. Angkasa I No.2 Kemayoran \\ Jakarta Pusat, DKI Jakarta \\ *E-mail : purwadi@bppt.go.id
}

\begin{abstract}
Intisari
Data meteorologi yang berupa citra/gambar sulit dianalisis dan dikombinasikan dengan data lain. Dalam tulisan ini akan dijelaskan metode pencuplikan citra/gambar radar yang dipublikasikan oleh BMKG menjadi data teks. Proses pengolahan terdiri dari dua tahap yaitu proses pemetaan setiap pixel dalam citra radar menjadi koordinat bumi (latitude dan longitude) dan penentuan nilai echo radar (dBZ). Dari legenda pada citra radar didapatkan 9 pola warna RGB yang digunakan sebagai penentu nilai $d B Z$ setiap pixel dalam citra radar. Hasil pengolahan citra radar berupa data teks yang terdiri dari longitude, latitude, dan nilai dBZ. Untuk membandingkan dengan data asli, data radar teks hasil pengolahan ditampilkan pada Website Global Informasion System (WebGIS). Warna data radar pada WebGIS ditentukan dengan persamaan warna sebagai fungsi dari nilai dBZ. Secara kualitatif, hasil perbandingan gambar radar asli dengan data numerik yang ditampilkan pada WebGIS menunjukkan bahwa hasil data numerik cukup presisi pada posisi longitude dan latitude. Namun, dari segi nilai numerik echo radar (dBZ) yang dihasilkan terdeteksi kurang akurat pada batas awan karena latar belakang gambar yang berwarna hitam.
\end{abstract}

Kata kunci : Citra Radar, Pengolahan Citra, Echo Radar, WebGIS.

\begin{abstract}
Meteorological data in the form of image has difficulty in further analysis such as to combine the data with other data sources. In this research, the proposed method for converting image data into texts using image processing for BMKG data provided is presented. The processing scenarios consist of two main steps; mapping process of every pixel of the images into the earth coordinate (latitude and longitude) step and radar echo values estimation in $\mathrm{dBZ}$ step. From the analysis, the 9 color patterns of RGB are obtained and used as the $d B Z$ justification tool for the pixel color of radar image. The results of this image processing step are the texts data of latitude, longitude and the radar echo values in $\mathrm{dBZ}$. In order to compare the analysis results with the original data, the processing data are then reshown to global information system website (WebGIS). The radar color data on WebGIS is determined based on color equation as a function of the echo radar. Qualitatively, the results of this comparison show that the numerical data results are precise in terms of longitude and latitude positions. However, in terms of numerical values echo radar (dBZ), the results perform less accurate especially on the boundary of the cloud due to the black color of background image.
\end{abstract}

Keywords : Radar Image, Image Processing, Echo Radar, WebGIS.

\section{PENDAHULUAN}

Badan Meteorologi Klimatologi dan Geofisika (BMKG) merupakan Badan pemerintah yang bertanggung jawab dalam bidang-bidang yang terkait dengan metereologi, klimatologi, dan geofisika. BMKG menyediakan berbagai informasi terkait dengan cuaca dan iklim untuk masyarakat. Informasi prakiraan cuaca berdasarkan data radar sangat penting bagi BMKG dalam memberikan peringatan dini cuaca ekstrim. Saat ini, BMKG memiliki setidaknya tiga format data radar cuaca yang berasal dari tiga produsen radar yakni Gematronik, Enterprise Electronics Corporation (EEC) dan Baron yang hanya dapat diolah menggunakan perangkat lunak dari masing-masing produsen radar (Permana et al., 2016). 
Radar Doppler C-Band bekerja berdasarkan prinsip Doppler sehingga sering disebut dengan Doppler Radar. Jenis Doppler Radar adalah satu-satunya instrumen penginderaan jauh yang dapat mendeteksi jejak angin dan mengukur kecepatan radial, baik dalam udara yang bersih ataupun dalam lokasi curah hujan yang lebat yang ditutupi oleh awan. Namun, Radar Cuaca Doppler C-Band juga memiliki kelemahan seperti keterbatasan rekaman terhadap topografi. Misalnya untuk daerah pegunungan maka hasil radar di daerah yang tertutupi pegunungan akan berkurang keakuratan datanya (Darmawan \& Matondang, 2013).

Radar cuaca Doppler C-Band memiliki kemampuan untuk mendeteksi badai, angin siklon tropis, hujan ektrim, berbagai fenomena penting yang berkaitan dengan cuaca termasuk untuk prediksi ke depan jumlah curah hujan secara kuantitatif yang akan terjadi mendatang (Diao et al, 2011).

Data curah hujan hasil pengukuran radar disediakan dalam bentuk file gambar dengan ekstensi *.png. Data ini dapat diunduh http://radar.bmkg.go.id/bmkg2/imageQC/. Arsip data radar tersebut tersedia hingga 7 hari kebelakang. Data radar yang berupa gambar tidak dapat diolah maupun dikombinasikan dengan data lain. Oleh karena itu data radar ini akan lebih bernilai jika disajikan dalam bentuk numerik sehingga dapat diolah maupun dikombinasikan dengan data lain agar lebih informatif.

Kurang akuratnya hasil analisis cuaca dapat disebabkan oleh banyak faktor, salah satunya karena kurang jelasnya citra awan dan jumlah awan yang berada di atas permukaan bumi hasil pencitraan satelit cuaca sehingga sulit untuk melakukan analisis cuaca pada suatu kota atau wilayah. Untuk itu salah satu solusi yang dapat digunakan adalah penggunaan teknologi pengolahan citra digital dan data pengamatan jumlah awan untuk membantu analisis cuaca (Santi, 2011).

Dalam tulisan ini akan dibahas teknik pengambilan data radar dari data citra radar. Data yang dihasilkan berupa data numerik yang dapat diolah secara lebih lanjut. Data hasil pengolahan citra radar ini akan memberikan nilai yang lebih terutama dalam kegiatan operasional yang terkait dengan informasi awan dan kejadian hujan.

Dengan data numerik ini dapat dibuat informasi dini tentang pembentukan awan. Informasi dini pembentukan awan ini akan sangat bermanfaat dalam kegiatan penyemaian awan pada operasi teknologi modifikasi cuaca (TMC). Selain itu, dengan melakukan overlay data ini dengan jalur penyemaian awan (track seeding) maka akan diketahui seberapa tepat proses penyemaian awan dilaksanakan.

\section{METODE}

\subsection{Gambar}

Dalam dunia ilmu komputer secara garis besar gambar dibagi 2 jenis yaitu gambar vektor dan gambar bitmap. Gambar vektor merupakan objek gambar yang dibentuk melalui kombinasi titik-titik dan garis dengan menggunakan rumusan matematika tertentu. Sedangkan gambar bitmap merupakan objek gambar yang dibentuk berdasarkan titik-titik (pixel) dan kombinasi warna (Ahmad \& Fardausy, 2005).

Dengan kata lain, gambar bitmap (atau gambar raster) adalah sebuah struktur data yang mewakili susunan pixel warna yang ditampilkan pada layar monitor, kertas atau media tampilan lainnya. Secara teknis gambar bitmap digambarkan dengan lebar dan tinggi dalam pixel dan dalam angka bit per pixel. Beberapa format gambar bitmap yang sering dijumpai adalah GIF, JPEG, BMP dan PNG.

PNG (Portable Network Graphics) dikembangkan sebagai alternatif lain untuk GIF, yang menggunakan paten dari LZW-algoritma kompresi. Format gambar PNG ini mendukung gambar kelas 24-bit seperti JPG dan kelas 8-bit seperti GIF. Pada kelas 8-bit terdiri dari 256 warna. Setiap warna pada pixel merupakan kombinasi dari warna dasar Blue (B), Green (G), $\operatorname{Red}(R)$ atau sering disingkat dengan RGB. Warna-warna lain dapat dibentuk dengan mengatur intensitas setiap warna dasar. Contoh, warna kuning merupakan kombinasi warna merah dengan hijau sehingga nilai RGB: 0255 255.

\subsection{Citra Radar}

Citra radar cuaca menggambarkan potensi intensitas curah hujan yang dideteksi oleh radar cuaca (Wardoyo, 2013). Pengukuran intensitas curah hujan (presipitasi) oleh radar cuaca berdasarkan seberapa besar pancaran energi radar yang dipantulkan kembali oleh butiranbutiran air di dalam awan dan digambarkan dengan produk Reflectivity yang memiliki besaran satuan dBZ (decibel) (Rinehart, 2010).

Makin besar energi pantul yang diterima radar maka makin besar juga nilai dBZ, dan semakin besar nilai dBZ reflectivity menunjukkan intensitas hujan yang terjadi semakin besar. Jangkauan terjauh/maksimum produk Reflectivity dari radar BMKG adalah sekitar $240 \mathrm{~km}$ dari lokasi radar (sumber: BMKG).

Skala dBZ pada legenda berkisar 5-75 yang dinyatakan dengan gradasi warna biru langit hingga ungu muda. Jika gradasi warna semakin ke arah ungu maka semakin tinggi intensitas hujannya. Kisaran intensitas hujan berdasarkan skala warna dBZ dan $\mathrm{mm} / \mathrm{jam}$ disajikan seperti dalam Tabel 1 berikut. 
Tabel 1. Kategori Intensitas Hujan Berdasarkan Nilai $\mathrm{dBZ}$.

\begin{tabular}{|c|c|c|}
\hline $\begin{array}{c}\text { Kategori Intensitas } \\
\text { Hujan }\end{array}$ & Nilai dBZ & $\mathrm{mm} / \mathrm{Jam}$ \\
\hline Hujan ringan & $30 \mathrm{~s} / \mathrm{d} 38$ & $1 \mathrm{~s} / \mathrm{d} 5$ \\
\hline Hujan sedang & $38 \mathrm{~s} / \mathrm{d} 48$ & $5 \mathrm{~s} / \mathrm{d} 10$ \\
\hline Hujan lebat & $48 \mathrm{~s} / \mathrm{d} 58$ & $10 \mathrm{~s} / \mathrm{d} 20$ \\
\hline Hujan sangat lebat & $>58$ & $>20$ \\
\hline \multicolumn{2}{|c|}{ sumber: http://bmkg.go.id/cuaca/citra-radar.bmkg }
\end{tabular}

\subsection{Teknik Penentuan Koordinat}

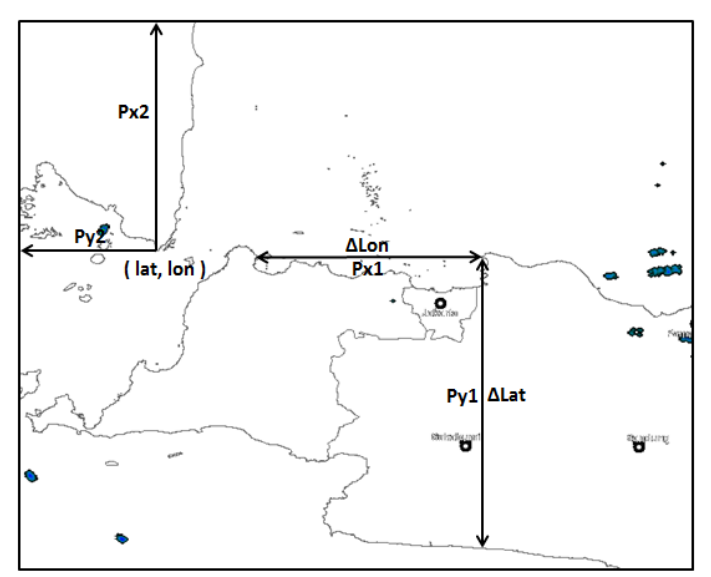

Gambar 1. Teknik penentuan koordinat.

Penentuan koordinat setiap pixel gambar dicari dengan dua tahap yaitu menentukan resolusi latitude dan longitude setiap pixel dan kemudian menentukan koordinat pixel $(0,0)$ di pojok kiri atas dari gambar. Penentuan resolusi longitude per pixel pada gambar dicari dengan membagi jarak longitude $(\Delta$ Lon) dengan panjang pixel (Px1). Metode yang sama juga diterapkan pada resolusi latitude yaitu membagi jarak latitude ( $\Delta$ Lat) dengan panjang pixel (py1).

Setelah ditemukan resolusi longitude dan latitude pixel pada gambar radar, maka langkah selanjutnya adalah menentukan koordinat pixel $(0,0)$ pada gambar radar. Pertama, titik acuan ditentukan terlebih dahulu. Titik acuan dipilih pada sudut atau gambar peta yang unik dan mudah dikenali. Pada tulisan ini dipilih Tanjung Tua dengan koordinat latitude -5.906 dan longitude 105.717 sebagai titik acuan, seperti terlihat pada Gambar 1. Setelah ditentukan koordinat titik acuan selanjutnya mencari pajang pixel pada titik acuan ke batas kiri gambar sebagai Px2 dan ke batas atas gambar sebagai Py2. Longitude pixel $(0,0)$ didapatkan dari longitude acuan dikurangi perkalian antara resolusi longitude dengan panjang pixel Px2. Sedangkan Latitude pixel $(0,0)$ didapatakan dari latitude titik acuan ditambah perkalian antara resolusi latitude dengan panjang pixel Py2.

\subsection{Teknik Mendapatkan Nilai dBZ}

Nilai dBZ dicari dengan mencocokkan warna pixel pada peta dengan nilai yang tertera pada legenda gambar radar. Legenda pada gambar radar terdiri dari warna gambar yang bergradasi dari biru hingga ungu dengan rentang nilai antara 5 hingga $75 \mathrm{dBZ}$. Warna pixel pada legenda diurai menjadi kombinasi warna RGB sehingga membentuk grafik pada Gambar 2.

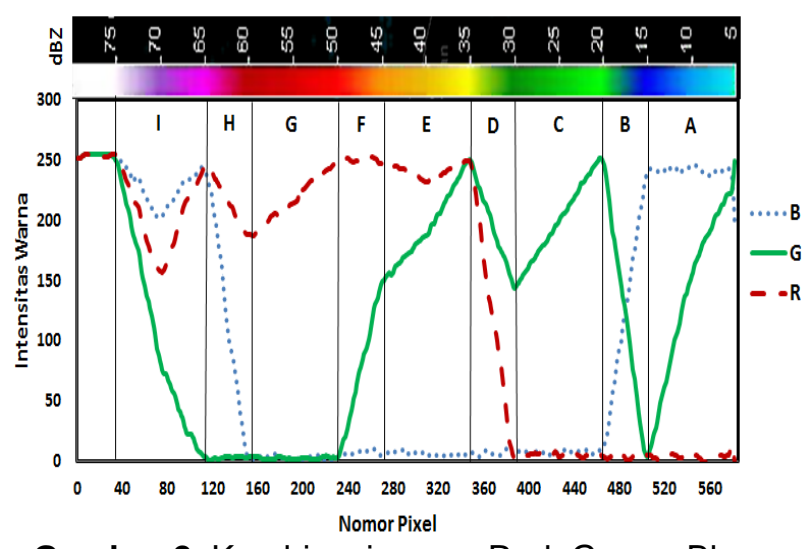

Gambar 2. Kombinasi warna Red, Green, Blue (RGB) pada legenda citra radar.

Dari Gambar 2, terlihat bahwa kombinasi warna RGB pada legenda citra radar memiliki pola yang dapat dikenali setiap interval $\sim 80$ atau $\sim 40$ pixel, ditunjukkan oleh pola $\mathrm{A}$ hingga $\mathrm{I}$. Dengan pola kombinasi warna yang berbeda ini, nilai $\mathrm{dBZ}$ dapat ditentukan. Penentuan nilai $\mathrm{dBZ}$ pada setiap pola akan dijelaskan sebagai berikut:

\subsubsection{Pola A (5-15 dBZ)}

Pola $A$ mengkondisikan untuk pencarian nilai 5-15dBZ. Dari pola tersebut kondisi $B>210$ dan $R<25$ sebagai kondisi pada rentang nilai $\mathrm{dBZ}$ ini, sedangkan $\mathrm{G}$ sebagai penentu nilai $\mathrm{dBZ}$. Nilai intensitas warna hujau pada kondisi pola $A$ dibuat grafik terhadap rentang nilai dBZ 5-15 menghasilkan grafik pada Gambar 3. Grafik tersebut apabila dilakukan regresi pada software excel akan menghasilkan persamaan y sebagai fungsi $x$ (nilai $d B Z$ sabagai fungsi dari nilai intensitas warna hijau/green) dengan nilai $r$ square 0.9913 .

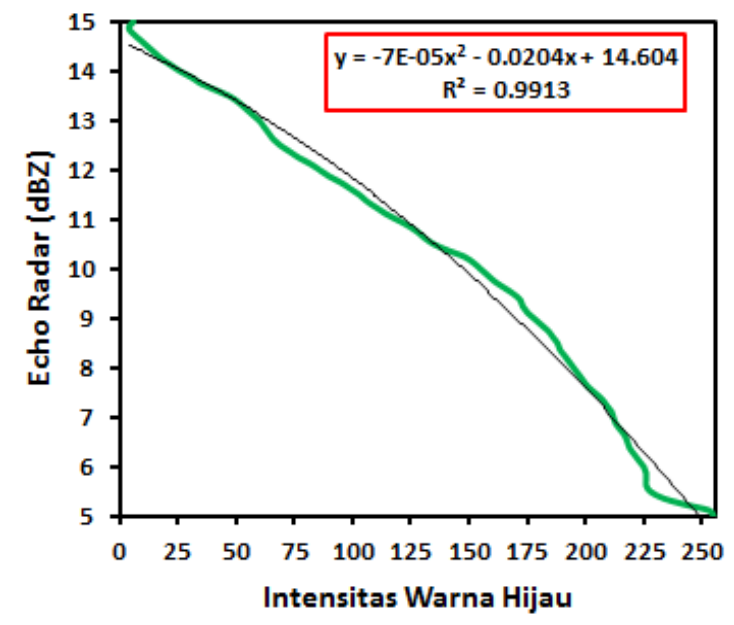

Gambar 3. Grafik intensitas warna hijau terhadap nilai Echo Radar (dBZ) pada Pola A. 


\subsubsection{Pola B (15-20 dBZ)}

Pola B menunjukkan kondisi untuk menentukan nilai dBZ dalam rentang 15-20 dBZ. Dari pola tersebut kondisi $20<\mathrm{B}<250$ dan $\mathrm{R}<$ 25 sebagai kondisi pada rentang 15-20 dBZ, sedangkan $G$ sebagai penentu nilai dBZ. Nilai intensitas Green pada kondisi pola B dibuat grafik terhadap rentang nilai 15-20 dBZ menghasilkan grafik pada Gambar 4. Grafik tersebut apabila dilakukan regresi linear pada software excel akan menghasilkan persamaan y sebagai fungsi $x$ dengan nilai $r$ square 0.9978 .

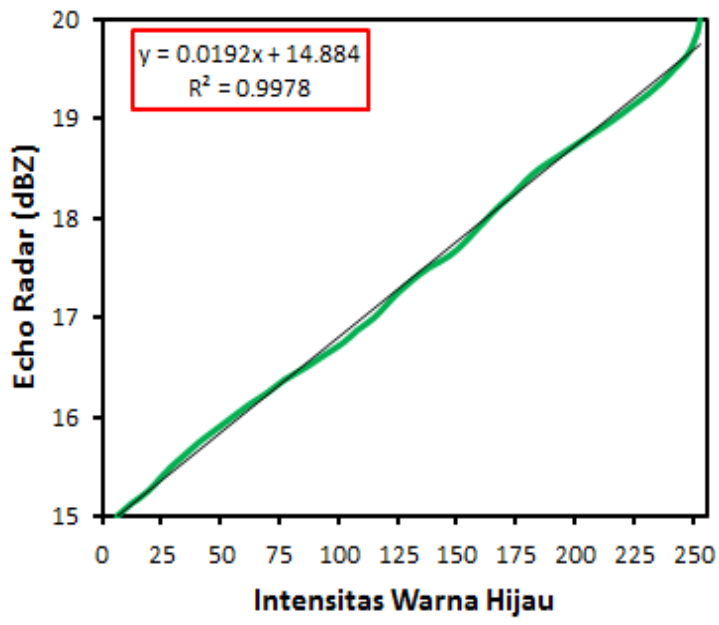

Gambar 4. Grafik intensitas warna hijau terhadap nilai Echo Radar (dBZ) pada Pola B.

\subsubsection{Pola C (20-30 dBZ)}

Pola C mengkondisikan untuk pencarian nilai 20-30 dBZ. Dari pola tersebut kondisi $B<25$, $G>140$, dan $R<25$ sebagai kondisi rentang nilai pada pola $C$, sedangkan $G$ sebagai penentu nilai dBZ. Nilai intensitas hijau pada kondisi pola $C$ dibuat grafik terhadap rentang nilai 20-30 dBZ menghasilkan grafik pada Gambar 5. Grafik tersebut apabila dilakukan regresi pada software excel akan menghasilkan persamaan y sebagai fungsi $x$ dengan nilai $r$ square 0.9971 .

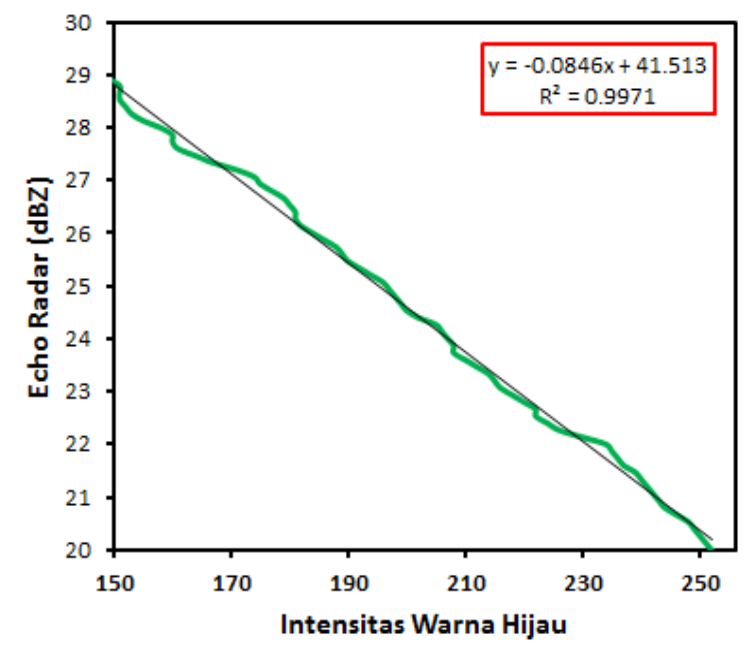

Gambar 5. Grafik intensitas warna hijau terhadap nilai Echo Radar (dBZ) pada Pola C.

\subsubsection{Pola $D(30-35 d B Z)$}

Pola D mengkondisikan untuk pencarian nilai 30-35 dBZ. Dari pola tersebut kondisi $B<25$ dan $G>140$ sebagai kondisi rentang nilai 30-35 $d B Z$, sedangkan $R$ sebagai penentu nilai $d B Z$. Nilai intensitas Red (Merah) pada kondisi pola D dibuat grafik terhadap rentang nilai 30-35 dBZ menghasilkan grafik pada Gambar 6. Grafik tersebut apabila dilakukan regresi pada software excel akan menghasilkan persamaan y sebagai fungsi $x$ dengan nilai $r$ square 0.9984 .

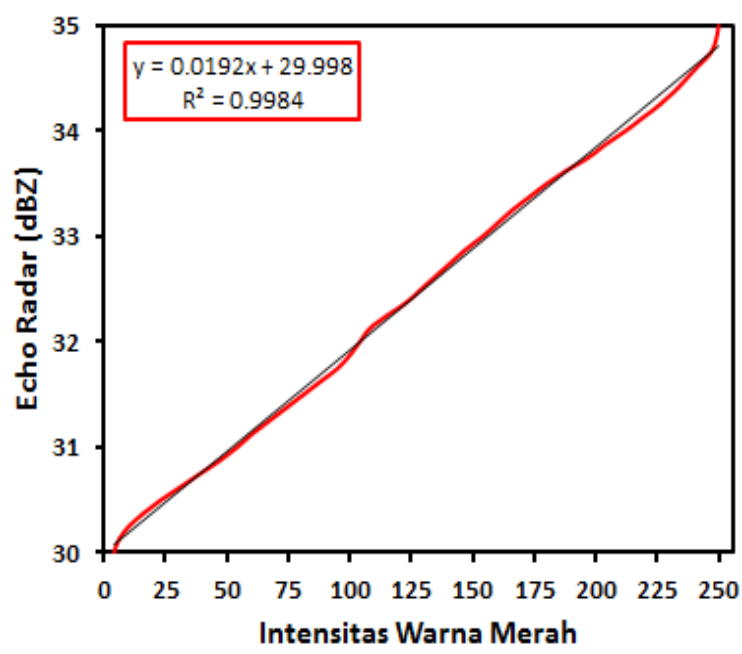

Gambar 6. Grafik intensitas warna merah terhadap nilai Echo Radar (dBZ) pada Pola D.

\subsubsection{Pola E (35-45 dBZ)}

Pola $E$ mengkondisikan untuk pencarian nilai 35-45 dBZ. Dari pola tersebut kondisi $\mathrm{B}<25$, $\mathrm{G}>150$ dan $\mathrm{R}>255$ sebagai kondisi rentang nilai 35-45 dBZ, selain sebagai kondisi, G juga berfungsi sebagai penentu nilai dBZ. Nilai intensitas warna hijau pada kondisi pola $E$ dibuat grafik terhadap rentang nilai 35-45 dBZ menghasilkan grafik pada Gambar 7. Kemudian dilakukan regresi dengan software excel akan menghasilkan persamaan $y$ sebagai fungsi $x$ dengan nilai $r$ square 0.9712 .

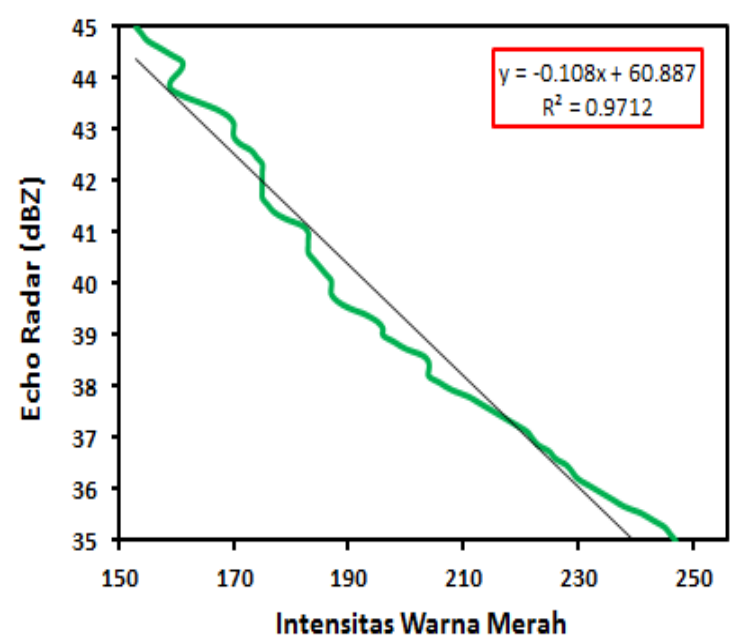

Gambar 7. Grafik intensitas warna hijau terhadap nilai Echo Radar (dBZ) pada Pola E. 


\subsubsection{Pola F (45-50 dBZ)}

Pola $F$ mengkondisikan untuk pencarian nilai $45-50 \mathrm{dBZ}$. Dari pola tersebut kondisi $\mathrm{B}<$ $25, \mathrm{G}<=150$ dan $\mathrm{R}>225$ sebagai kondisi rentang nilai $45-50 \mathrm{dBZ}$. Selain $\mathrm{G}$ sebagai salah satu kondisi, $G$ juga sebagai penentu nilai $d B Z$. Nilai intensitas Green (Hijau) pada kondisi pola E dibuat grafik terhadap rentang nilai $45-50 \mathrm{dBZ}$ menghasilkan grafik pada Gambar 8. Kemudian dilakukan regresi dengan software excel akan menghasilkan persamaan $y$ sebagai fungsi $x$ dengan nilai $r$ square 0.9948 .

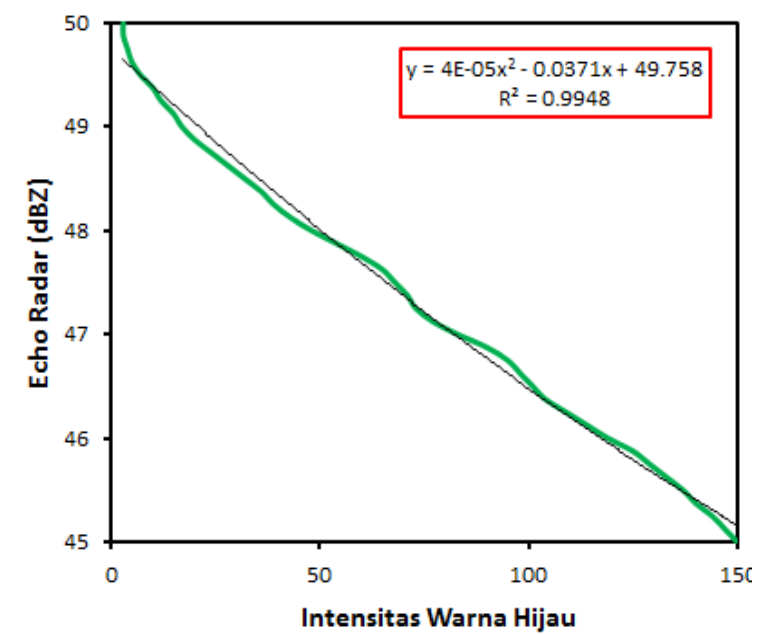

Gambar 8. Grafik intensitas warna hijau terhadap nilai Echo Radar (dBZ) pada Pola F.

\subsubsection{Pola G (50-60 dBZ)}

Pola $G$ mengkondisikan untuk pencarian nilai 50-60 dBZ. Dari pola tersebut kondisi $B<$ $25, G<25$ dan $R>175$ sebagai kondisi rentang nilai 50-60 dBZ. Selain $R$ sebagai salah satu kondisi, $R$ juga sebagai penentu nilai $d B Z$. Nilai intensitas merah pada kondisi pola $G$ dibuat grafik terhadap rentang nilai 50-60 dBZ menghasilkan grafik pada Gambar 9. Kemudian dilakukan regresi dengan software excel akan menghasilkan persamaan y sebagai fungsi dengan nilai $r$ square 0.9876 .

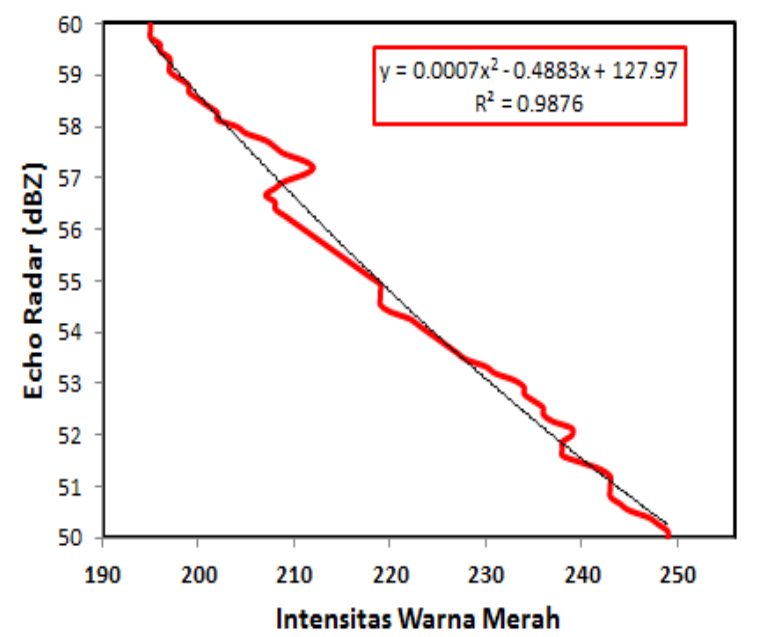

Gambar 9. Grafik intensitas warna merah terhadap nilai Echo Radar (dBZ) pada Pola G.

\subsubsection{Pola $H$ (60-65 dBZ)}

Pola $\mathrm{H}$ mengkondisikan untuk pencarian nilai 60-65 dBZ. Dari pola tersebut kondisi $\mathrm{G}<25$ dan $R>180$ sebagai kondisi rentang nilai 60-65 $d B Z$. Selain $R$ sebagai salah satu kondisi, $R$ juga sebagai penentu nilai dBZ. Nilai intensitas Red (Merah) pada kondisi pola $\mathrm{H}$ dibuat grafik terhadap rentang nilai 60-65 dBZ menghasilkan grafik pada Gambar 10. Kemudian dilakukan regresi dengan software excel akan menghasilkan persamaan $y$ sebagai fungsi $x$ dengan nilai $r$ square 0.9923 .

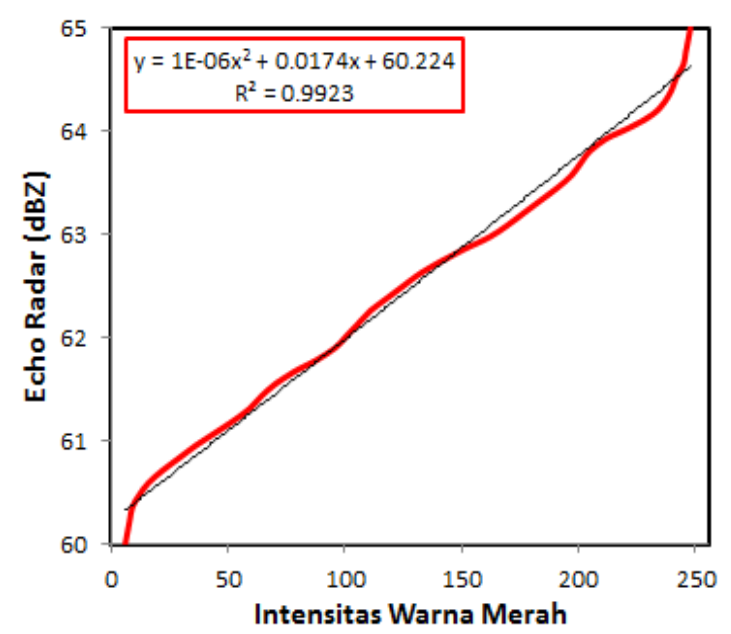

Gambar 10. Grafik intensitas warna merah terhadap nilai Echo Radar (dBZ) pada Pola H.

\subsubsection{Pola I (65-75 dBZ)}

Pola I mengkondisikan untuk pencarian nilai $65-75 \mathrm{dBZ}$. Dari pola tersebut kondisi $200<$ $B<250,150<R<250$ sebagai kondisi rentang nilai 65-75 dBZ. Sedangkan G sebagai penentu nilai dBZ. Nilai intensitas warna hijau pada kondisi pola I dibuat grafik terhadap rentang nilai 65-75 dBZ menghasilkan grafik pada Gambar 11. Kemudian dilakukan regresi dengan software excel akan menghasilkan persamaan y sebagai fungsi $x$ dengan nilai $r$ square 0.9904 .

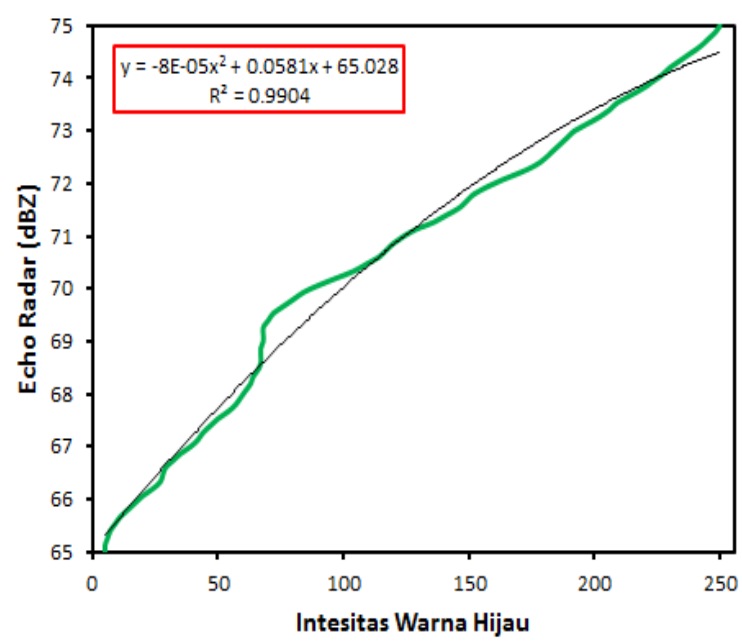

Gambar 11. Grafik intensitas warna hijau terhadap nilai Echo Radar (dBZ) pada Pola I. 


\subsection{Evaluasi Hasil Proses Konversi Data Citra Radar}

Hasil proses konversi data citra radar dievaluasi dengan menampilkan kembali data tersebut ke dalam website global information system (WebGIS). Dengan menampilkan data teks menjadi data gambar pada WebGIS maka hasil proses konversi dapat dibandingkan dengan citra radar aslinya. Dalam tulisan ini, perbandingan gambar asli dengan hasil konversi dilakukan secara visual dengan memberikan nilai kesesuaian secara kualititatif.

Untuk lebih mempermudah melakukan perbandingan gambar asli dengan gambar hasil pengolahan maka citra gambar hasil pengolahan diberikan warna yang mengikuti gambar aslinya. Pemberian warna pada setiap pixel data hasill konversi dilakukan dengan membuat persamaan balik yaitu intensitas warna sebagai fungsi dari nilai dBZ (pada persamaan Tabel 2, dBZ=x). Nilai komponen warna BGR dalam setiap pola ditampilkan dalam Tabel 2.

Tabel 2. Nilai Komponen Warna BGR untuk Menampilkan Data Radar pada WebGIS.

\begin{tabular}{|c|c|c|c|}
\hline Pola & $B$ & $\mathrm{G}$ & $R$ \\
\hline A & 255 & $\begin{array}{c}1.2473 x^{2}- \\
0.24 x+ \\
275.58\end{array}$ & 0 \\
\hline B & $\begin{array}{c}46.564 \mathrm{x}+ \\
919.1\end{array}$ & $\begin{array}{c}51.912 x- \\
772.37\end{array}$ & 0 \\
\hline C & 0 & $\begin{array}{c}-11.788 x+ \\
489.9\end{array}$ & 0 \\
\hline$D$ & 0 & $\begin{array}{c}22.348 x- \\
526.57\end{array}$ & $\begin{array}{l}51.9 x- \\
1556.7\end{array}$ \\
\hline$E$ & 0 & $\begin{array}{c}-8.9966 x+ \\
553.35\end{array}$ & 255 \\
\hline$F$ & 0 & $\begin{array}{c}1.5979 x^{2}- \\
183.96 x+ \\
5198.3\end{array}$ & 255 \\
\hline $\mathrm{G}$ & 0 & (1) & $\begin{array}{c}0.1397 x^{2}- \\
20.99 x+ \\
950.52\end{array}$ \\
\hline $\mathrm{H}$ & $\begin{array}{c}-0.4157 x^{2}+ \\
107.81 x- \\
4984.7\end{array}$ & 0 & $\begin{array}{c}-0.7474 x^{2}+ \\
106.45 x- \\
3508.3\end{array}$ \\
\hline I & $\begin{array}{c}1.7803 x^{2}- \\
247.55 x+ \\
8815.6\end{array}$ & $\begin{array}{c}1.4019 x^{2}- \\
170.65 x+ \\
5174.8\end{array}$ & $\begin{array}{c}3.5144 x^{2}- \\
489.72 x+ \\
17233\end{array}$ \\
\hline
\end{tabular}

\section{HASIL DAN PEMBAHASAN}

Dalam tulisan ini digunakan citra radar Tangerang tanggal 23 Februari 2017 pukul 10.00 UTC sebagai contoh dalam proses konversi data citra radar kedalam data teks. BMKG menyediakan 2 jenis data citra/radar yaitu; dengan latar satelit (zoomBlueMarble) dan latar berwana hitam (zoomBlackMarble). Dalam proses ini dipilih citra radar dengan latar warna hitam untuk lebih memudahkan dalam proses pengambilan data. Data teks yang dihasilkan meliputi koordinat dan nilai dBZ pada lokasi tersebut. Dalam proses pencarian koordinat setiap pixel dalam citra radar maka harus ditentukan terlebih dahulu koordinat pixel $(0,0)$. Seperti yang telah dijelaskan dalam metode penelitian, maka langkah pertama yang harus dilakukan adalah mencari resolusi pixel dalam satuan koordinat bumi. Dalam proses ini dinggunakan perangkat lunak Photoshop CS4 dan dilakukan secara manual. Hasil dari proses ini adalah didapatkannya rumusan pemetaan setiap pixel dalam koordinat bumi. Selanjutnya, rumusan pemetaan setiap pixel dikodekan dalam script berbahasa python untuk memetakan setiap pixel yang termasuk dalam 9 kombinasi warna dari legenda pada citra radar. Apabila warna pixel tidak termasuk 9 kombinasi warna maka pixel tersebut dianggap tidak ada data.

Dari hasil perhitungan resolusi setiap pixel, diperoleh jarak antar pixel secara horizontal dalam satuan derajat sebesar $0.0036^{\circ}$ yang mewakili resolusi maksimum jarak longitude. Sedangkan pada arah vertikal diperoleh resolusi maksimum sebesar $0.0048^{\circ}$ yang mewakili resolusi jarak latitude. Perbedaan ini menunjukkan bahwa gambar radar yang disediakan oleh BMKG, memanjang ke arah bawah atau ke arah utara dan selatan. Hasil perhitungan dengan Tanjung Tua (latitude -5.906 dan longitude 105.717) sebagai titik acuan, didapatkan koordinat pixel $(0,0)$ dengan latitude 4.725 dan longitude 105.190. Dalam perhitungan ini, akan dicari nilai radar dalam interval $0.005^{\circ}$ atau sekitar 550 meter.

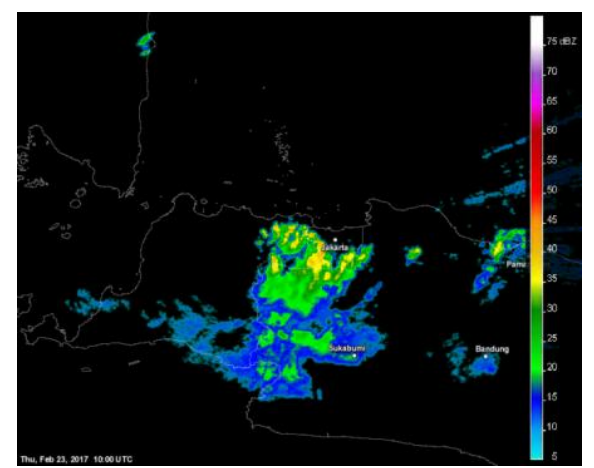

Gambar 12. Citra radar tanggal 23 Februari 2017 pukul 10.00 UTC.

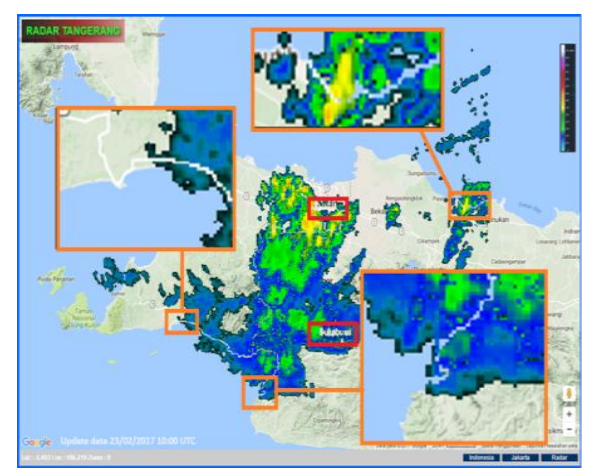

Gambar 13. Hasil pengolahan citra radar tanggal 23 Februari 2017 pukul 10.00 UTC. 
Secara visual gambar hasil pengolahan (Gambar 13) menunjukkan gambar yang identik dengan gambar aslinya (Gambar 12). Selain itu, dari beberapa posisi perbesaran pada batas pantai dan batas administrasi menunjukkan posisi yang berimpit. Sehingga dapat disimpulkan dengan teknik ini, citra radar dapat dipetakan secara akurat. Garis pantai dan administrasi pada Gambar 13 di atas muncul karena garis tersebut nampak pada gambar aslinya berupa warna abu-abu. Warna garis abu-abu tidak masuk kedalam 9 pola pada legenda citra radar, sehingga dalam data hasil pengolahan menunjukkan nilai pixel yang kosong/tidak ada data.

Warna pada gambar asli dan pengolahan menunjukkan nilai echo radar (dBZ). Hasil tampilan citra radar hasil pengolahan menunjukkan warna yang hampir sama dengan citra radar aslinya. Namun, beberapa titik pixel terutama di pinggir echo radar menunjukkan warna biru yang agak kehitaman. Hal ini terjadi karena efek latar belakang dari data asli yang berwarna hitam yang membuat pinggiran citra radar terpengaruh.

Selain itu, pada garis batas pulau dan administrasi menunjukkan data hasil pengolahan kosong pada beberapa pixel. Hal ini juga terjadi pada beberapa tulisan nama kota yang terlihat diatas citra radar aslinya seperti "Jakarta" dan "Sukabumi", ditunjukkan dalam kotak warna merah pada gambar 13. Untuk mengatasi masalah ini diperlukan teknik yang lebih lanjut untuk menutupi kekosongan data pada pixel-pixel tersebut seperti dengan teknik interpolasi dari pixel disampingnya.

Metode pencuplikan nilai echo radar dengan referensi spasial dan kombinasi warna RGB ini dapat diaplikasikan pada gambar/citra raster lainnya dengan mangacu pada contoh citra yang digunakan pada tulisan ini. Berdasarkan contoh citra yang digunakan, maka gambar/citra yang dapat dicuplik nilai datanya dengan metode ini diharuskan memiliki latar yang berbeda dengan warna data yang akan dicuplik. Selain itu gambar atau citra harus memiliki legenda sebagai referensi penentuan nilai citra/gambar yang akan dicuplik.

\section{KESIMPULAN}

Metode/teknik pencuplikan data dari citra radar yang berupa file gambar telah dilakukan dan menghasilkan data yang cukup akurat dalam hal posisi letak citra dan juga nilai hasil pencuplikan terhadap gambar aslinya. Penentuan letak citra dilakukan dengan memetakan posisi setiap pixel pada citra radar. Sedangkan, nilai hasil pencuplikan ditentukan dari pola warna RGB pada legenda gambar.

Hasil pengolahan dapat ditampilkan berupa WebGIS sehingga diperoleh gambar yang lebih informatif dibanding gambar aslinya.

Pola warna pada tampilan WebGIS diperoleh dengan membuat persamaan balik pada setiap pola pada legenda gambar asli. Dari teknik ini masih ditemukan beberapa kekurangan dimana pada area garis batas pulau, garis batas administrasi, dan nama kota bernilai kosong. Sehingga, untuk penggunaan lebih lanjut diperlukan metode interpolasi dari warna pixel disekitar area tersebut.

\section{DAFTAR PUSTAKA}

Achmad, B., Fardausy, K. (2005). Teknik Pengolahan Citra Digital. Yogyakarta : Ardi Publishing.

Diao, X., Zhu, J., Liu, Z. (2011). Analysis of Three Supercell Storms with Doppler Weather Radar Data. Acta Meteorologi Sinica, 25(2), 211-223. doi: 10.1007/S13351-011-00285

Darmawan, Y., Matondang, C.A. (2013). Sensitivitas Radar Cuaca Doppler C-Band (CDR) terhadap Kejadian Angin Puting Beliung di Kecamatan Siborongborong Tanggal 29 Januari 2013. Prosiding Workshop Radar Dan Satelit Cuaca Vol: 1, Desember 2013.

Danoedoro, P. (1996). Pengolahan Citra Digital; Teori dan Aplikasinya. Yogyakarta: Fakultas Geografi UGM.

Jensen, J.R. (2005). Introductory Digital Image Processing: A Remote Sensing Perspective, $3^{\text {rd }}$ ed. Sydney: Pearson Prentice Hall.

Permana, D.S., Hutapea, T.D.F., Praja, A.S., Fatkhuroyan., Muzayanah, L.F. (2016). Pengolahan Multi Data Format Radar Cuaca Menggunakan Wradlib Berbasis Python. Jurnal Meteorologi Dan Geofisika, 17(3), 157-164.

Rinehart, R.E. (2010). Radar for Meteorologists (Fifth Edition). Rinehart Publications, 5, 136-139.

Rigo, T., Llasat, M.C. (2007). Analysis of Mesoscale Convective Systems in Catalonia Using Meteorological Radar for the Period 1996-2000. Atmospheric Research, 83, 458-472. doi: 10.1016/J.Atmosres.2005.10.016

Santi, R.C.N. (2011). Teknik Perbaikan Kualitas Citra Satelit Cuaca dengan Sataid. Jurnal Teknologi Informasi DINAMIK, 16(2), 101109.

Sebastianelli, S., Russo, F., Napolitano, F., Baldini, L. (2010). Comparison between Radar and Rain Gauges Data at Different Distances from Radar and Correlation Existing between the Rainfall Values in the Adjacent Pixels. Hydrology And Earth System Sciences Discussions, 7(4), 51715212. 
Siswanto. (2008). Panduan Erdas Imagine Pengolahan Citra Satelit untuk Pertanian. Jawa Timur: Penerbit UPN Press.

Sutanto, A., Trisakti, B., Arimurthy, A.M. (2014). Perbandingan Klasifikasi Berbasis Obyek dan Klasifikasi Berbasis Piksel pada Data Citra Satelit Synthetic Aperture Radar untuk Pemetaan Lahan. Jurnal Penginderaan Jauh dan Pengolahan Data Citra Digital, 11(1), 63-75.

Wardoyo, E. (2013). Radar Cuaca - Pengantar II. Materi Produk Radar. Jakarta. 